Canadian

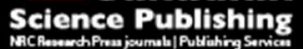

Botany

Botanique

\title{
Cross-incompatibility and self-incompatibility: unrelated phenomena in wild and cultivated potatoes?
}

\begin{tabular}{|r|l|}
\hline Journal: & Botany \\
\hline Manuscript ID & cjb-2017-0070.R3 \\
\hline Manuscript Type: & Article \\
\hline Date Submitted by the Author: & 06-Oct-2017 \\
\hline Complete List of Authors: & $\begin{array}{l}\text { Maune, Juan; Universidad Nacional de Mar del Plata Facultad de Ciencias } \\
\text { Agrarias, Introducción a las Ciencias Agrarias } \\
\text { Camadro, Elsa; INTA-UNMdP-CONICET } \\
\text { Erazzú, Luis; Instituto Nacional de Tecnologia Agropecuaria, EEA Famaillá }\end{array}$ \\
\hline $\begin{array}{r}\text { Is the invited manuscript for } \\
\text { consideration in a Special } \\
\text { Issue? : }\end{array}$ & N/A \\
\hline Keyword: & $\begin{array}{l}\text { hybridization barriers, cross-incompatibility, wild and cultivated potatoes, } \\
\text { self-incompatibility, pollen-pistil relationships }\end{array}$ \\
\hline & \multicolumn{2}{|c}{} \\
\hline
\end{tabular}

\section{SCHOLARONE}

Manuscripts 
Cross-incompatibility and self-incompatibility: unrelated phenomena in wild and cultivated potatoes?

Juan Federico Maune ${ }^{1}$, Elsa Lucila Camadro ${ }^{1,2}$, Luis Ernesto Erazzú ${ }^{3}$

${ }^{1}$ Facultad de Ciencias Agrarias (FCA), Universidad Nacional de Mar del Plata (UNMdP). Ruta Nacional 226

Km 73.5, (7620) Balcarce, Buenos Aires, Argentina. ${ }^{2}$ Instituto Nacional de Tecnología Agropecuaria (INTA), Centro Regional Buenos Aires Sur (CERBAS), Estación Experimental Agropecuaria (EEA) “Domingo R. Pasquale”, Ruta Nacional 226 Km 73.5 (7620), Balcarce, Buenos Aires, Argentina; Consejo Nacional de Investigaciones Científicas y Técnicas (CONICET). ${ }^{3}$ INTA, Centro Regional Tucumán-Santiago del Estero, EEA Famaillá, Ruta Provincial 301 km 32, (4132) Famaillá, Tucumán, Argentina, and Universidad Nacional de Tucumán, Facultad de Agronomía y Zootecnia.

Author for correspondence:

Elsa L. Camadro

Genetics Laboratory-PROPAPA, INTA, CERBAS, EEA “Domingo R. Pasquale”, Ruta Nacional 226 Km 73.5, (7620) Balcarce, Buenos Aires, Argentina.

Tel: +54 2266439100 ext. 401

Fax: +542266439101

Email: camadro.elsa@,inta.gob.ar 
ABSTRACT

Knowledge of internal hybridization barriers is relevant for germplasm conservation and utilization. The two pre-zygotic barriers are pollen-pistil self-incompatibility (SI) and cross-incompatibility (CI). To ascertain if SI and CI were phenotypically related phenomena in potatoes, extensive intra- and interspecific, both intra- and interploidy breeding relationships were established, without previous assumptions on the compatibility behavior of the studied germplasm. Pollen-pistil relationships were analyzed at the individual genotype/accession/family level. In two seasons, 828 intra- and interspecific genotypic combinations were performed, using accessions of the wild potatoes Solanum chacoense $(2 n=2 x=24)$, S. gourlayi $(2 n=2 x=24$; $2 \mathrm{n}=4 \mathrm{x}=48)$ and $S$. spegazzinii $(2 \mathrm{n}=2 \mathrm{x}=24)$, full-sib families $(2 \mathrm{n}=2 \mathrm{x}=24)$ within/between the latter two diploids, and S. tuberosum $(2 \mathrm{n}=4 \mathrm{x}=48)$ cultivars. Pollen-pistil incompatibility occurred in the upper first third of the style $\left(\mathrm{I}_{1 / 3}\right)$ in all selfed diploids. In both intra- and interspecific combinations, the most frequent relationship was compatibility, followed by $\mathrm{I}_{1 / 3}$, but incompatibility also occurred in the stigma and the style (middle third and bottom third). We observed segregation for these relationships in full-sib families, and unilateral and bilateral incompatibility in reciprocal crosses between functional SI genotypes. Crossincompatibility in potatoes is, apparently, controlled by genes independent of the $S$-locus or its $S$-haplotype recognition region (although molecular evidences are needed to confirm it), with segregation even within accessions.

Key words: hybridization barriers; pollen-pistil relationships; cross-incompatibility; self-incompatibility; wild and cultivated potatoes 


\section{INTRODUCTION}

The two species concepts most frequently used in plant and animal taxonomy are the Taxonomic Species Concept (TSC) and the Biological Species Concept (BSC) which are based, respectively, on morphological phenotypes and breeding relationships (Grant 1981). Higher plants are usually classified according to the TSC, by comparison of morphological phenotypes of individual plants with holotypes (physical samples or illustrations of complete -or part of- single specimens that were used when the species was described for the first time) or other types when holotypes are not available (McNeil et al. 2012). Molecular characterization is sometimes considered in addition to morphology (Soltis and Soltis 1995).

Under the TSC, taxonomists artificially establish limits between species based exclusively on phenotype, with an underlying assumption that "species" are at the end of their evolutionary process and, therefore, are static and invariable over time. According to the BSC, however, species are groups of actually or potentially interbreeding natural populations which are reproductively isolated from other such groups (Mayr 1963). The BSC provides a good approximation to the actual situation in nature even though asexual reproduction is excluded and limits between species are not easy to establish. It is also of greater value than the TSC for devising breeding strategies aimed at increasing the genetic variability of crop species through the introgression of desirable traits from their wild relatives (crop wild relatives= CWR).

In higher plants, reproductive isolation is the consequence of the action of several breeding barriers. These can be either external (e.g., geographical, temporal, mechanical, among others) or internal. The latter -which are expressed in the plant tissues themselves- can be either pre-zygotic or post-zygotic, depending on whether they occur before or after fertilization (Hadley and Openshaw 1980; see Camadro et al. 2004 for examples in potatoes). The two pre-zygotic hybridization barriers that act at the pollen-pistil level, preventing pollen tubes from reaching the eggs, are self-incompatibility (SI) and cross-incompatibility (CI). The former promotes allogamy and the second establishes limits to gene flow, which eventually could lead to (or reinforce) speciation (de Nettancourt 2001).

\section{Self-incompatibility}

In plants with SI systems, inbreeding is restricted by self-discrimination between pollen and pistil, in a process genetically regulated by one or more highly polymorphic loci (de Nettancourt 2001). The $S$-locus is 
the most extensively studied because it is present in valuable species of the Rosaceae, Solanaceae and Gramineae families (see de Nettancourt 2001). The $S$-locus reactions are classified as either sporophytic (SSI) or gametophytic (GSI), depending on whether the $S$-haplotype expressed by a pollen grain is determined, respectively, by the genotype of the pollen parent or by its own genotype (de Nettancourt 2001). GSI occurs in potatoes, which belong to the Solanaceae family, where the $S$-locus is complex and includes tightly-linked genes: one $S$-RNAse and multiple $S L F$ (see Entani et al. 2014).The incompatibility reaction occurs when pistils and pollen in a given genotypic combination co-express the same $S$-haplotype.

In the GSI system, pollen germination occurs normally, but pollen tube growth is arrested mainly in the upper portion of the style (Lush and Clarke 1997; see de Nettancourt 2001; Hayes et al. 2005; Covey et al. 2010).

The GSI reaction can be broken down by mutations in the SI genes themselves (see de Nettancourt 2001), the

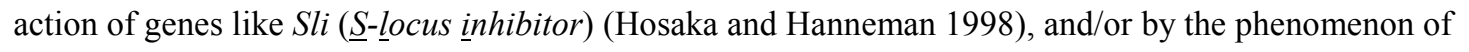
"competitive interaction" in diploid (or higher ploidy) pollen grains carrying two (or more) different $S$ haplotypes, which explains the ability of polyploids with GSI to produce seed after selfing (de Nettancourt 2001).

\section{Cross-incompatibility}

CI has been defined as any relationship (or its absence) between pollen and pistil which prevents hybrid zygote formation in crosses between two fertile species (de Nettancourt 2001). This phenomenon has been proposed to occur from a lack of genetic information in one of the partners of a given genotypic combination about either the structure or the physiology of the other partner (Hogenboom 1973), or for pistil recognition of pollen with a foreign origin (Kermicle and Evans 2010). CI can be either unilateral or bilateral, depending on whether a given genotypic combination is, respectively, compatible in only one direction or in both directions of the cross. Arrest of pollen tube growth in CI can occur at various sites of the pistil (stigma; upper, middle or bottom part of the style) or in the ovary, as observed in various members of the Solanaceae family: wild potatoes (Camadro and Peloquin 1981; Hayes et al. 2005), wild tomatoes (Baek et al. 2015) and pepper (Onus and Pickersgill 2004).

The "SI x SC" rule 
Most CI studies have been focused on the unilateral type and designed by taking into consideration Lewis and Crowe's (1958) "SI x SC" rule, under the assumption that the $S$-locus is involved in the CI reaction (see Liedl et al. 1996; Covey et al. 2010; Li and Chetelat 2010; Tovar-Méndez et al. 2014; Baek et al. 2015). According to this rule, pollen-pistil relationships between SI and SC individual plants/species/populations are dependent on the crossing direction, being incompatible in the SI x SC direction but compatible in the reciprocal cross. In tomatoes and tobacco (Solanaceae), evidence for the involvement of S-RNases in pollen rejection has been provided under this crossing scheme (Murfett et al. 1996; McClure et al. 2000; Cruz-Garcia et al. 2003;

Covey et al. 2010; Tovar-Méndez et al. 2014; Baek et al. 2015). The success of interspecific crosses in various plant groups can be explained by the "SI x SC" rule. However, there are many exceptions, such as the finding of compatibility in SI x SC crosses (see Eijlander et al. 2000), and incompatibility in other SC - SI combinations (Hermsen and Ramanna 1976; Camadro and Peloquin 1981; de Nettancourt 2001; Hayes et al. 2005; Baek et al. 2015). The "SI x SC" rule fails to explain bilateral CI; moreover, CI has been reported in allogamous species without a GSI S-locus system such as maize (Kermicle and Evans 2005, 2010) and carrot (Ibañez and Camadro 2015), and in a dioecious species, garden asparagus (Marcellán and Camadro 1996).

\section{Potatoes}

The common potato, Solanum tuberosum L. ssp. tuberosum (tbr, $2 n=4 x=48$ ), has a narrow genetic base but approximately 100 (Spooner et al. 2014) to 200 (Hawkes 1990) CWR with a wide geographical and ecological distribution in the American continent. These species form a ploidy series with $2 \mathrm{n}=2 \mathrm{x}, 3 \mathrm{x}, 4 \mathrm{x}, 5 \mathrm{x}$ and 6x $(\mathrm{x}=12)$ (Hawkes 1990). Due to their adaptation to a range of habitats, wild potatoes are an important source of genetic diversity for cultivar breeding by conventional crossing methods (Jansky et al. 2013) because genome differentiation in the group is scarce (Matsubayashi 1991).

Samples of cultivated potatoes and their CWR are available at germplasm banks, where they are conserved and multiplied as accessions, usually under taxonomic species status (Jansky et al. 2013). Ex situ multiplication by sexual reproduction is conducted under the assumption that plants within an accession can be freely intercrossed. However, SI and CI can either hinder or prevent hybridization not only between accessions but within accessions as well (see Camadro et al. 2004).

Wild and cultivated potatoes have a multialellic $S$-locus GSI system. Diploid cytotypes are obligate outcrossers (unless they carry rare self-compatibility alleles), polysomic polyploids are outcrossers which can 
self-pollinate (due to competitive interaction), and disomic polyploids are autogamous, apparently because competitive interaction occurs between $S$-haplotypes of the different genomes (Camadro et al. 1992), in a manner resembling Mac Key's (1970) fixed heterozygosity concept in polyploid wheats.

Knowledge of internal hybridization barriers is relevant for devising germplasm conservation and utilization strategies in crops. Whereas SI has been studied extensively, much remains to be known about CI. Thus, the objectives of this work were to (1) detect the presence of pre-zygotic breeding barriers in wild and cultivated potatoes in an extensive network of breeding relationships, without previous assumptions on the SI or SC behavior of the plant materials; (2) discern whether the incompatible reactions at the phenotypic level could be attributed to the action of the $S$-locus or other (as yet unknown) locus (loci); (3) select genotypic combinations for conducting future studies on the molecular basis of the CI phenomena in this plant group. Herein we report the results of controlled crosses -both intra- and interspecific (according to the current taxonomic status of the plant materials), and intra- and inter-ploidy- that were analyzed at the level of individual genotypes/accessions/families, in order to understand the relationship between the two pre-zygotic reproductive barriers at the phenotypic level.

\section{MATERIALS AND METHODS}

\section{Plant materials}

Crossing was conducted in two seasons. In the first season (season 1: summer 2006/2007), plants were obtained from both botanical seeds (one plant= one genotype) of the taxonomic species $S$. gourlayi Hawkes $\left(\operatorname{grl}^{1} ; 2 \mathrm{n}=2 \mathrm{x}=24\right.$ and $\left.2 \mathrm{n}=4 \mathrm{x}=48\right)$ and $S$. spegazzinii Bitter $\left(\operatorname{spg}^{1} ; 2 \mathrm{n}=2 \mathrm{x}=24\right)$, provided by the Potato Germplasm Bank of E.E.A. Balcarce, INTA, Argentina, and tubers of five commercial cultivars (one cultivar= one cloned genotype) of $S$. tuberosum ssp. tuberosum L. ( $\left.\operatorname{tbr}^{1} ; 2 \mathrm{n}=4 \mathrm{x}=48\right)$. In the second season (season 2 : summer 2009/2010) plants were obtained from botanical seeds of (a) two accessions of the taxonomic species S. chacoense Bitter (chc; $2 \mathrm{n}=2 \mathrm{x}=24$ ) and (b) full-sib families obtained in season 1 from compatible intra- and interspecific crosses between individual plants of grl and spg accessions, and from tubers of three commercial tbr cultivars (Table 1). Ten or more plants were used per accession, when possible, in each season. Individual

\footnotetext{
${ }^{1}$ Abbreviations according to Simmonds (1963)
} 
genotypes were identified according to the denomination of the accession or family to which they belong, followed by a dot and a number, e.g., "OL4911.19” corresponds to genotype 19 of accession OL4911, and “(OL4911.19 x Oka5649.16).4” corresponds to genotype 4 of the intra-specific (OL4911.19 x Oka5649.16) family.

\section{Crossing work}

Seeds were placed overnight in a gibberellic acid $\left(\mathrm{GA}_{3}\right)$ solution $(1500 \mathrm{ppm})$ and then sown in Petri dishes for germination. At the 2-3 leaves stage, plantlets were transplanted into pots in a screenhouse, where they were grown under similar management practices for performing the crossing work. At flowering, and depending on the number of available flower buds, each plant to be used as a pistillate parent was crossed to one or more plants (pollen parent) to generate various genotypic combinations. Only buds emasculated one day before anthesis were pollinated early in the morning, either with fresh pollen (if available) or with pollen stored at $4^{\circ}$ $\mathrm{C}$ (viability $\geq 60 \%$ ), following an incomplete diallel mating design because the number of flower buds per genotype was limited and there were differences in flowering time among the genotypes. The genotypic combinations were intraspecific and interspecific, classified according to the current status of the progenitors for ex situ conservation in the germplasm bank. They were performed under similar environmental conditions, both within and between families or accessions; whenever possible, reciprocal crosses were also generated. To study pollen-pistil relationships, at least three pistils were pollinated for each genotypic combination on the same day when possible, then fixed in FAA (1:1:8 v/v/v, formaline: glacial acetic acid: $96 \%$ ethanol) $48 \mathrm{~h}$ after pollination.

\section{Pollen-pistil relationships}

Fixed pistils were processed and stained with a solution of $0.1 \%$ aniline-blue in $0.1 \mathrm{~N} \mathrm{~K}_{3} \mathrm{PO}_{4}$ according to Martin (1959), mounted with a drop of glycerol on a glass slide, gently squashed with a cover slip and observed in an optical microscope with UV light. Pollen-pistil relationships were classified as either compatible or incompatible depending, respectively, on whether pollen tubes reached the ovary or not. The compatible class included both fully compatible and partially compatible combinations, to avoid erroneous interpretations because abundant pollen was placed on the stigmas and not all pollen tubes reach the ovary even in fully compatible combinations. Incompatible relationships were classified according to the site of pollen tube arrest (Camadro and Peloquin 1981): stigma $\left(\mathrm{I}_{\mathrm{S}}\right)$ and, from stigma to ovary, upper third $\left(\mathrm{I}_{1 / 3}\right)$, 
second third $\left(\mathrm{I}_{2 / 3}\right)$, and bottom third $\left(\mathrm{I}_{3 / 3}\right)$ of the style. Pistils with ungerminated pollen were not considered in the analysis; those in which more than one site of pollen tube arrest was observed were classified according to the site at which the majority of the pollen tubes was arrested.

\section{RESULTS}

\section{Pollen-pistil relationships}

A total of 828 (673 in season 1 and 155 in season 2) genotypic combinations were analyzed over two seasons, and included the microscopic observation of 2,681 pollinated pistils. Compatible and incompatible pollenpistil relationships were observed in both seasons (Fig. 1). Compatibility (in 615 combinations) and $\mathrm{I}_{1 / 3}$ (in 136 combinations) were the most frequent pollen-pistil relationships observed in both intraspecific (including self-pollinations) and the interspecific crosses. In all self-pollinated pistils of the diploid genotypes, pollen tube growth was arrested in the upper third of the style. In both intraspecific (both within and between accession/family) and interspecific genotypic combinations, $\mathrm{I}_{\mathrm{S}}, \mathrm{I}_{2 / 3}$ and $\mathrm{I}_{3 / 3}$ were observed (Tables $2, \mathrm{~S} 1$ and $\mathrm{S} 2)$.

When pollen-pistil relationships were analyzed by considering the ploidy level of the progenitors (Tables S1 and S2), compatibility was the most frequent relationship observed regardless of whether the genotypic combinations were intra- or inter-ploidy, and intra- or interspecific (Table 3). The results of the intraspecific and interspecific intra-ploidy $2 \times 1 \times 2 \times$ combinations were similar (compatibility and incompatibility at the four sites, although the percentage of combinations that fell into each incompatibility category varied). In the intraploid $4 \mathrm{x} \times 4 \mathrm{x}$ genotypic combinations, the incompatibility sites were $\mathrm{I}_{1 / 3}$ and $\mathrm{I}_{2 / 3}$ in the intraspecific, and these sites plus $\mathrm{I}_{\mathrm{S}}$ in the interspecific ones. For the interploid $2 \mathrm{x} x 4 \mathrm{x}$ combinations, only compatibility was observed in the intraspecific ones, whereas compatibility followed by $\mathrm{I}_{1 / 3}$ were the most frequent relationships in the interspecific combinations, followed by $\mathrm{I}_{\mathrm{S}}$ and $\mathrm{I}_{2 / 3}$. In the interploid intraspecific $4 \mathrm{x}$ x $2 \mathrm{x}$ genotypic combinations, incompatibility was observed in all sites except $\mathrm{I}_{3 / 3}$, whereas incompatibility was observed at each site, $\mathrm{I}_{1 / 3}$ being the most frequent, in the interspecific crosses.

\section{IC genes segregation}

In general, more than one pollen-pistil relationship was observed when the genotypic combinations were analyzed at the level of (a) individual genotypes (regardless of the accession and family to which they belong) 
(Table 4), (b) accession and (c) family, when used as either the female or male parent (Tables S1 and S2). A similar behavior was observed when analyzing individual genotypic combinations at the level of interaccession/family/cultivar crosses (Table 5). Pollen-pistil relationships observed when individual genotypes participated in more than two genotypic combinations are presented in Table 4. If these genotypes exhibited: (a) only one relationship, it was invariably compatibility; (b) two relationships, the most frequent were compatibility and $\mathrm{I}_{1 / 3}$, although $\mathrm{I}_{\mathrm{S}}, \mathrm{I}_{2 / 3}$ or $\mathrm{I}_{3 / 3}$ were also observed; (c) more than two relationships, $\mathrm{I}_{\mathrm{S}}, \mathrm{I}_{2 / 3}$ and/or $\mathrm{I}_{3 / 3}$ were observed in addition to compatibility and/or $\mathrm{I}_{1 / 3}$. The genotypes that exhibited four types of pollenpistil relationships participated in five to 32 genotypic combinations as either the male or female parent. The five types of relationships were observed in one genotype which had participated as the female parent in 41 genotypic combinations (data not shown). Various individual plants obtained in season 2 from fully compatible genotypic combinations (carried out in season 1) between progenitors that were also compatible in other intra- and inter-specific genotypic combinations, exhibited $\mathrm{I}_{\mathrm{S}}, \mathrm{I}_{2 / 3}$ and $\mathrm{I}_{3 / 3}$ when used as either the female and/or male parent in intra- and inter- accession/family crosses (Table 6, Fig.S1). In addition, two full-sib genotypes derived from an inter-specific spg-2x grl cross - (OL4916.13 x ORHL4841.2).4 and (OL4916.13 x ORHL4841.2).3-, exhibited various pollen-pistil relationships when crossed with APEC1.5 (chc); however, upon self-pollination, these three diploid genotypes were $\mathrm{I}_{1 / 3}$ (Fig. 2).

\section{Reciprocal genotypic combinations}

The number of reciprocal genotypic combinations that could be conducted was limited by the number of flowers and the flowering time of each genotype. In season 1, 107 reciprocal combinations were completed: 88 of these were compatible in both directions whereas 15 were compatible in one direction, one exhibited $\mathrm{I}_{1 / 3}$ in both directions, and three exhibited incompatibility but at different sites in each direction (i.e. $\mathrm{I}_{1 / 3}$ in one direction, and stigma in the reciprocal) (Table 7). In the 24 reciprocal genotypic combinations conducted in season 2, 11 were compatible in both directions, three exhibited $\mathrm{I}_{1 / 3}$ in both directions, two exhibited $\mathrm{I}_{2 / 3}$ in both directions, four were compatible in one direction, and two exhibited incompatibility at different sites (Table 7).

\section{DISCUSSION}

Wild potatoes are genetically very complex. Their breeding system provides for overlapping generations, and hybridization is a frequent phenomenon within and between ploidy levels and populations (Hawkes and 
Hjerting 1969; Masuelli et al. 2009) because breeding barriers, if present, can either be incomplete or circumvented (see Camadro et al. 2012). Moreover, their natural populations can be composed of plants with more than one ploidy level. Populations with diploid and tetraploid plants, for example, may produce numerically unreduced ( $2 \mathrm{n}$ ) pollen in addition to normal (n) pollen (respectively, $\mathrm{n}=\mathrm{x}$ and $2 \mathrm{n}=2 \mathrm{x}$ pollen in the diploids and $n=2 x$ and $2 n=4 x$ pollen in the tetraploids). In $2 x$ and higher ploidy pollen grains, competitive interaction can lead to SC relationships among plants with a GSI system. Despite these complexities, potato accessions are ex situ conserved and multiplied as Taxonomic Species (TS) (Camadro et al. 2012), and genetic experiments are designed under the assumption that potato TS and Biological Species (BS) are equivalent.

\section{Pollen-pistil relationships and the species concept in potatoes}

To pursue the objectives of this study, we created a network of breeding relationships with a wide genetic base, over two seasons. Compatibility was the most frequent pollen-pistil relationship observed, regardless of the origin and taxonomic status of the progenitors. In season 1, viable seeds were obtained from all pollenpistil compatible genotypic combinations, including those between grl and spg, which gave rise to the full-sib interspecific families used in season 2. These full-sib families, in turn, exhibited compatible pollen-pistil relationships in most genotypic combinations in which they were crossed, again regardless of the origin and taxonomic classification of the other progenitor. These results contrast with the expected if TS and BS were equivalent in potatoes, and point out to the feasibility of gene flow among sympatric natural populations of different TS. In fact, various authors have reported the occurrence of natural interspecific wild potato hybrids (see Hawkes and Hjerting 1969; Camadro et al. 2004, 2012; Masuelli et al. 2009; Spooner et al. 2014), and morphological, genetic and molecular data obtained by Bedonni and Camadro (2009) have revealed the occurrence of gene flow among sympatric populations of four TS.

In our study, most genotypic combinations were compatible; notwithstanding, incompatible reactions were observed upon selfing and inter-crossing. Upon selfing of the diploid genotypes, pollen tube growth arrest invariably occurred in $\mathrm{I}_{1 / 3}$, a reaction reported as characteristic of the GSI system in the Solanaceae family (Lush and Clarke 1997; de Nettancourt 2001; Hayes et al. 2005; Covey et al. 2010). Upon inter-crossing, the incompatible reaction sites in intra- (intra- and inter-accession) and inter-specific genotypic combinations were similar: $I_{1 / 3}$, reported as characteristic of both GSI and CI (Ascher and Peloquin 1968; Camadro and Peloquin 1981; Lush and Clarke 1997; Camadro et al. 2004; Hayes et al. 2005; Covey et al. 2010); and $\mathrm{I}_{\mathrm{S}}, \mathrm{I}_{2 / 3}$ 
and $\mathrm{I}_{3 / 3}$, reported as characteristic of CI (Ascher and Peloquin 1968; Camadro and Peloquin 1981; Camadro et al. 2004; Hayes et al. 2005; Baek et al. 2015).

Pollen-pistil hybridization barriers were incomplete in our plant materials, although they are ex situ conserved under TS status. Population systems between early and late stages of speciation, at various stages of divergence and reproductive isolation, and interconnected by a reduced amount of interbreeding and gene flow are referred to as semispecies (Grant 1981). If this were the case in wild potatoes, segregation for genes controlling hybridization barriers would be present within accessions -as we observed in our materialshighlighting the previously discussed lack of agreement between the TS and the BS in this plant group. Concomitantly, segregation for morphological traits is expected to occur. The appearance of morphologically "off-type" plants during the ex situ multiplication process at germplasm banks (see Camadro 2012) gives additional support this assertion.

\section{GSI vs. CI at the phenotypic level}

A first clue to phenotypically differentiate GSI from CI would be given by the results of reciprocal crosses at the individual genotypic combination level. In this regard, the number of reciprocal crosses that could be carried out in our study was limited by the number of available flowers for pollination. Even though cloning in potatoes could be an alternative to circumvent this limitation, the number of plants needed to test all possible genotypic combinations could become unmanageable. Thus, we used an incomplete diallel crossing design with reciprocal crosses when possible. Based on the action of the GSI S-locus, reciprocal crosses are expected to be either fully or partially compatible (both recorded as compatible in our study), or incompatible $\left(\mathrm{I}_{1 / 3}\right)$ in both directions. But, in addition to the expected reactions, we observed either unilateral incompatibility, or bilateral incompatibility with different reaction sites in each crossing direction, both in intraspecific intraploid (SI x SI) and interspecific intraploid (SI x SI and SC x SC) crosses, as well as in interploid (SI x SC) ones. These results cannot be explained by the action of the $S$-locus alone or, at least, of its specificity. The expression of $I_{1 / 3}$ in the interspecific combinations is another reaction that cannot be explained by the action of the $S$-locus alone. It is highly unlikely that genetic materials of such a wide geographic provenience, as the ones we used, would have shared the $S$-haplotypes. Moreover, the offspring from compatible genotypic combinations exhibited $\mathrm{CI}$ (in addition to compatibility and/or $\mathrm{I}_{1 / 3}$ ) upon crossing with other genotypes. These results can be explained by assuming segregation for the gene(s) controlling 
pollen-pistil barriers, as it was previously hypothesized by Camadro and Peloquin (1981), Eijlander et al. (2000), and Hayes et al. (2005) for other wild and cultivated potato materials.

\section{The "SI x SC" rule}

In potatoes, Hermsen et al. $(1974,1977)$ approached the study of interspecific crosses between S. tuberosum haploids (2x, SI) and the wild potato S. verrucosum (2x, SC) from the "SI x SC" rule. They observed unilateral incompatibility as predicted but, exceptionally, some of the SI genotypes acted as "acceptors" of the SC pollen. In a line of reasoning similar to that of Camadro and Peloquin (1981) and Hayes et al. (2005), these authors and Eijlander et al. (1977) proposed the action of a dominant allele not belonging to the $S$-locus (and expressed in the absence of an inhibitor gene) to explain this behavior. In a detailed analysis of male and female fertile backcross progenies from these materials, Eijlander et al. (2000) observed SC in $\mathrm{F}_{1}$ populations, with segregation into SC and SI genotypes in later generations although in skewed ratios. Thus, they proposed a complex model, involving at least four different loci for explaining the appearance and disappearance of SC in the offspring generations. In this regard, our study included crosses in all $2 \mathrm{x}-4 \mathrm{x}$ intra- and inter-specific combinations, and variable and unpredictable pollen-pistil relationships were observed. Under the assumption that each $2 \mathrm{x}$ is $\mathrm{SI}$ and that each $4 \mathrm{x}$ could be $\mathrm{SC}$ due to the competitive interaction, it can be concluded that the "SI x SC" rule does not work in our materials. Also, the observation of variable-although similar- pollen-pistil relationships in all 2x-4x interspecific combination could not be explained by the specificity of the GSI $S$ locus. For example, if the results of 4x x 2x (SC x SI) and 2x x 4x (SI x SC) combinations in our materials would have depended on the action of the GSI S-locus, more compatible pollen-pistil relationships would have been expected in the second type of combination due to competitive interaction in the $2 \mathrm{x} S$-heterozygous pollen from the $4 \mathrm{x}$ parent. However, we observed the same variability for pollen-pistil relationships in both crossing directions.

In tomatoes, which also belong to the Solanaceae family, Liedl et al. (1996), Covey et al. (2010), Li and Chetelat (2010) and Baek et al. (2015) studied CI at the level of accessions of the same or different TS. Pollen-pistil relationships in intra- and interspecific crosses were studied under the "SI x SC" rule. They used species/accessions as the experimental units; therefore, only one type of relationship was reported for each combination. This rule presupposes that all genotypes belonging to the same accession would exhibit the 
same reaction upon crossing with another accession/species (that is, the character is fixed) and that this reaction can be predicted if the $\mathrm{SI}$ or $\mathrm{SC}$ of the materials is known.

\section{Level of analysis}

Due to their obligate allogamy, SI plants in general are expected to be heterozygous and their populations heterogeneous, whereas SC plants are expected to be homozygous and their populations more or less homogeneous, depending on whether they have a percentage of allogamy (Camadro 2012). Thus, genetic experiments carried out with a few genotypes per accession and/or few accessions per TS species entail the idea that accessions/populations are genetically homogeneous, and that strong breeding barriers have developed between sympatric populations, preserving the genetic identity of the species.

Potatoes are genetically very complex and, as previously stated, competitive interaction in diploid and higher ploidy pollen grains provides for SC in plants with a GSI system. Therefore, to avoid underestimation of population variability for genes controlling pre-zygotic barriers, we analyzed pollen-pistil relationships at the level of individual genotype $\mathrm{x}$ genotype combinations. This approach revealed that a single genotype could exhibit various pollen-pistil relationships depending on the genotype of the other parent, and whether it was used as either the male or the female parent. A similar behavior was observed when the analysis was conducted with individual genotypes at the level of accession/family/cultivar. In this regard, by increasing the number of genotypic combinations in which a given genotype was involved, the probability of detecting different types of pollen-pistil relationships was increased, independently of the accession/species to which it belonged. These results provide further evidence of the inconsistency of the taxonomical classification based on morphological phenotypes, because pollen behavior upon pollination depended on the interaction between the genotypes involved in a given cross rather than on the accession/species to which they belonged, as Camadro and Peloquin (1981) and Raimondi and Camadro (2003) had reported. They also indicate the need of working at the level of individual genotypic combinations.

\section{CONCLUSIONS}

The results of the extensive breeding network reported in this paper allow us to conclude that TS and BS are not equivalent in potatoes. They also allow us to hypothesize that SI and CI in this plant group are two different phenomena at the phenotypic level, and that the $S$-locus (or at least its specificity) is apparently not 
involved in the latter because its action cannot be explained by the observed segregation for sites of pollen tube arrest. However, to exclude the $S$-locus action from the CI phenomenon in potatoes, it is necessary to conduct molecular studies at the level of gene expression in compatible and incompatible genotypic combinations. To that end, it is first necessary to perform a phenotypic study at the individual plant level to select the appropriate genotypes for the crossing work.

For applied purposes, the discrepancies between TS and BS in this plant group, the observed variability for pollen-pistil relationships within accessions, and the fact that genotypes within a given accession can exhibit CI upon intercrossing should be considered for both selection of parents and strategies to facilitate the breeding process, reducing operational costs, and devising ex situ conservation and multiplication strategies to avoid or minimize the loss of genetic diversity "captured" from the natural populations in the accessions, as a main objective of active germplasm banks (see Camadro 2012).

\section{ACKNOWLEDGEMENT}

To Instituto Nacional de Tecnología Agropecuaria (INTA), Universidad Nacional de Mar del Plata (UNMdP), Consejo Nacional de Investigaciones Científicas y Técnicas (CONICET) and Fondo para la Investigación Científica y Tecnológica (FONCyT) for providing financial support. LEE and JFM had scholarships from Instituto Nacional de Tecnología Agropecuaria and Consejo Nacional de Investigaciones Científicas y Técnicas, respectively, for their doctoral thesis.

\section{REFERENCES}

Ascher, P.D., and Peloquin, S.J. 1968. Pollen tube growth and incompatibility following intra-and interspecific pollinations in Lilium longiflorum. Am. J. Bot. 55: 1230-1234.

Baek, Y.S.,Covey, P.A., Petersen, J.J., Chetelat, R.T., McClure, B.A., and Bendinger, P.A. 2015. Testing the SI $\times$ SC rule: Pollen-pistil interactions in interspecific crosses between members of the tomato clade (Solanum section Lycopersicon, Solanaceae). Am. J. Bot. 102: 302-311. doi:10.3732/ajb.1400484.

Bedonni, M.C., and Camadro, E.L. 2009. Morphological and molecular evidence of natural interspecific hybridization in the diploid potato Solanum kurtzianum from Argentina. Botany, 87: 78-87. doi:10.1139/B08116. 
Camadro, E.L. 2012. Relevance of the genetic structure of natural populations, and sampling and classification approaches for conservation and use of wild crop relatives: potato as an example. Botany, 90: 1065-1072. doi:10.1139/b2012-090.

Camadro, E.L., and Peloquin, S.J. 1981. Cross-incompatibility between two sympatric polyploid Solanum species. Theor. Appl. Genet. 60: 65-70. doi:10.1007/BF00282417.

Camadro, E.L., Masuelli, R.W., and Cortés, M.C. 1992. Haploids of the wild tetraploid potato S. acaule Bitt. ssp. acaule: generation, meiotic behavior and electrophoretic pattern for the aspartate aminotransferase (AAT) system. Genome, 35: 431-435. doi:10.1139/g92-064.

Camadro, E.L., Carputo, D., and Peloquin, S.J. 2004. Substitutes for genome differentiation in tuber-bearing Solanum: interspecific pollen-pistil incompatibility, nuclear-cytoplasmic male sterility, and endosperm. Theor. Appl. Genet. 109: 1369-1376. doi:10.1007/s00122-004-1753-2.

Camadro, E.L., Erazzú, L.E., Maune, J.F., and Bedogni, M.C. 2012. A genetic approach to the species problem in wild potato. Plant Biol. 14: 543-554. doi:10.1111/j.1438-8677.2012.00563.x.

Covey, P.A., Kondo, K., Welch, L., Frank, E., Sianta, S., Kumar, A., Nuñez, R. et al. 2010. Multiple features that distinguish unilateral incongruity and self-incompatibility in the tomato clade. Plant J. 64: 367-78. doi:10.1111/j.1365-313X.2010.04340.x.

Cruz-Garcia, F., Hancock, C.N., and McClure, B.A. 2003. S-RNase complexes and pollen rejection. J. Exp. Bot. 54: 123-130. doi:10.1093/jxb/erg045.

de Nettancourt, D. 2001. Incompatibility and Incongruity in Wild and Cultivated Plants (2nd ed.). SpringerVerlag, Berlin.

Eijlander, R., Ramanna, M.S., and Jacobsen, E. 1997. Selection of vigorous and fertile S-homo- and heterozygous tester clones from self-incompatible diploid potato, Solanum tuberosum L. Euphytica, 97: 97111. doi:10.1023/A:1003041006157.

Eijlander, R., Ter Laak, W., Hermsen, J. G. T., Ramanna, M. S., and Jacobsen, E. 2000. Occurrence of selfcompatibility, self-incompatibility and unilateral incompatibility after crossing diploid S. tuberosum (SI) with S. verrucosum (SC): I. Expression and inheritance of self-compatibility. Euphytica, 115: 127-139. doi:10.1023/A:1003902907599. 
Entani, T., Kubo, K., Isogai, S., FukaoY., Shirakawa, M., Isogai, A., and Takayama, S. 2014. Ubiquitinproteasome-mediated degradation of S-RNase in a solanaceous cross-compatibility reaction. Plant J. 78: 1014-1021. doi:10.1111/tpj.12528.

Erazzú, L. E., Camadro, E. L., and Clausen, A. M. 2009. Persistence over time, overlapping distribution and molecular indications of interspecific hybridization in wild potato populations of Northwest Argentina. Euphytica, 168:249-262. doi:10.1007/s10681-009-9938-z.

Grant, V. 1981. Plant speciation (2nd. ed.). Columbia University Press, New York.

Hadley, H.H., and Openshaw, S.J. 1980. Interspecific and intergeneric hybridization. In Hybridization of Crop Plants. Edited by W.R. Fehr and H.H. Hadley. ASA, CSSA, Madison, WI. pp 133-159.

Hawkes, J.G. 1990. The potato: evolution, biodiversity and genetic resources. Belhaven Press, London.

Hawkes, J. G., and Hjerting, J. P. 1969. The potatoes of Argentina, Brazil, Paraguay and Uruguay. A biosystematic study. Clarendon Press, Oxford.

Hayes, R.J., Dinu, I.I., and Thill, C.A. 2005. Unilateral and bilateral hybridization barriers in inter-series crosses of 4x 2EBN Solanum stoloniferum, S. pinnatisectum, S. cardiophyllum and 2x 2 EBN S.tuberosum haploids and haploid-species hybrids. Sex. Plant Reprod. 17: 303-311. doi:10.1007/s00497-005-0244-1.

Hermsen, J.G.Th., and Ramanna, M.S. 1976. Barriers to hybridization of Solanum bulbocastanum Dun. and S. verrucosum Schlechtd. and structural hybridity in their $F_{1}$ plants. Euphytica, 25: 1-10. doi:10.1007/BF00041523.

Hermsen, J.G.Th., Olsder, J., Hoving, E., and Jansen, P. 1974. Acceptance of self-compatible pollen from Solanum verrucosum in dihaploids from S. tuberosum. In Fertilization in Higher Plants. Edited by H.F. Linskens. pp. $37-40$.

Hermsen, J.G.Th., Govaert, I., Hoekstra, S., van Loon, C., and Neefjes, C. 1977. Analysis of the effect of parental genotypes on crossability of diploid Solanum tuberosum with $S$. verrucosum. A gene for gene relationship? Proceedings of the 8th Eucarpia Congress, Madrid, Spain, pp. 305-312.

Hogenboom, N.G. 1973. A model for incongruity in intimate partner relationship. Euphytica, 22: $219-233$. doi:10.1007/BF00022629. 
Hosaka, K., and Hanneman, R.E. 1998. Genetics of self-compatibility in a self-incompatible wild diploid potato species Solanum chacoense. 1. Detection of an S locus inhibitor (Sli) gene. Euphytica, 103: 265-271. doi:10.1023/A:1018353613431.

Ibañez, M.S., and Camadro, E.L. 2015. Reproductive behavior of the wild carrots Daucus pusillus and Daucus montanus from Argentina. Botany, 93: 279-286. doi:10.1139/cjb-2014-0243.

Jansky, S.H., Dempewolf, H., Camadro, E.L., Simon, R., Zimnoch-Guzowska, E., Bisognin, D.A., and Bonierbale, M. 2013. A case for crop wild relative preservation and use in potato. Crop Sci. 53: 746-754. doi:10.2135/cropsci2012.11.0627.

Kermicle, J.L., and Evans, M.M.S. 2005. Pollen-pistil barriers to crossing in maize and teosinte result from incongruity rather than active rejection. Sex. Plant Reprod. 18: 187-194. doi:10.1007/s00497-005-0012-2.

Kermicle, J.L., and Evans, M.M.S. 2010. The Zea mays sexual compatibility gene ga2: naturally occurring alleles, their distribution, and role in reproductive isolation. J. Hered. 101: 737-749.

doi:10.1093/jhered/esq090.

Lewis, D., and Crowe, L.K. 1958. Unilateral interspecific incompatibility in flowering plants. Heredity, 12: 233-256. doi:10.1038/hdy.1958.26.

Li, W., and Chetelat, R.T. 2010. A pollen factor linking inter- and intraspecific pollen rejection in tomato. Science, 330: 1827-1830. doi:10.1126/science.1197908.

Liedl, B.E., McCormick, S., and Mutschler, M.A. 1996. Unilateral incongruity in crosses involving Lycopersicon pennellii and L. esculentum is distinct from self-incompatibility in expression, timing and location. Sex. Plant Reprod. 9: 299-308. doi:10.1007/BF02152705.

Lush, W.M., and Clarke, A.E. 1997. Observations of pollen tube growth in Nicotiana alata and their implications for the mechanism of self-incompatibility. Sex. Plant Reprod. 10: 27-35. doi:27. doi: $10.1007 / \mathrm{s} 004970050064$.

Mac Key, J. 1970. Significance of matting systems for chromosomes and gametes in polyploids. Hereditas, 66: 1657-176. doi:10.1111/j.1601-5223.1970.tb02342.x.

Marcellán, O.N., and Camadro, E.L. 1996. Self- and cross-incompatibility in Asparagus officinalis and 
Asparagus densiflorus cv. Sprengeri. Can. J. Bot. 74: 1621-1625. doi:10.1139/b96-196.

Martin, F.W. 1959. Staining and observing pollen tubes in the style by means of fluorescence. Stain Technol.

34: 125-8. doi:10.3109/10520295909114663.

Masuelli, R.W., Camadro, E.L., Erazzú, L.E., Bedogni, M.C., and Marfil, C.F. 2009. Homoploid hybridization in the origin and evolution of wild diploid potato species. Plant Syst. Evol. 277:143-151.

doi:10.1007/s00606-008-0116-x.

Matsubayashi, M. 1991. Phylogenetic relationships in the potato and its related species. In Chromosome engineering in plants: genetics, breeding, evolution Part B. Edited by T. Tsuchiya and P.K. Gupta. Amsterdam, Elsevier, pp 93-118.

Mayr, E. 1963. Animal species and evolution. Harvard University Press, Cambridge, Massachusetts.

McClure, B.A., Beecher, B., and Sulaman,W. 2000. Factors affecting inter- and intra-specific pollen rejection in Nicotiana. Ann. Bot. 85:113-123. doi:10.1006/anbo.1999.1061.

McNeill, J., Barrie, F.R., Buck, W.R., Demoulin, V., Greuter, W., Hawksworth, D.L. et al. 2012. International Code of Nomenclature for algae, fungi, and plants (Melbourne Code) adopted by the Eighteenth International Botanical Congress Melbourne, Australia, July 2011. http://www.iapt-taxon.org/nomen/main.php.

Murfett, J., Strabala, T.J., Zurek, D.M., Mou, B., Beecher, B., and McClure, B.A. 1996. S RNase and interspecific pollen rejection in the genus Nicotiana: multiple pollen-rejection pathways contribute to unilateral incompatibility between self-incompatible and self-compatible species. Plant Cell, 8:943-958. doi:10.1105/tpc.8.6.943.

Onus, A.N., and Pickersgill, B. 2004. Unilateral incompatibility in Capsicum (Solanaceae): occurrence and taxonomic distribution. Ann. Bot. 94: 289-295. doi:10.1093/aob/mch139.

Raimondi, J.P., and Camadro, E.L. 2003. Crossability relationships between the common potato, Solanum tuberosum spp. tuberosum, and its wild diploid relatives S. kurtzianum and S. ruiz-lealii. Genet. Resour. Crop. Evol. 50: 307-314. doi:10.1023/A:1023532030996.

Simmonds, N.W. 1963. Abbreviation of potato names. Europ. Potato, 6: 186-190. doi:10.1007/BF02365786

Soltis, P.S., and Soltis, D.E. 1995. Plant molecular systematics. In: Evolutionary Biology. Edited by M.K. 
Hecht, R.J. Macintyre, and M.T. Clegg. Springer, New York, pp 139-194.

Spooner, D.M., Ghislain, M., Simon, R., Jansky, S.H., and Gavrilenko, T. 2014. Systematics, diversity, genetics, and evolution of wild and cultivated potatoes. Bot. Rev. 80: 283-383. doi:10.1007/s12229-0149146-y.

Tovar-Méndez, A., Kumar, A., Kondo, K., Ashford, A., Baek, Y.S., Welch, L., Bedinger, P.A., and McClure, B.A. 2014. Restoring pistil-side self-incompatibility factors recapitulates an interspecific reproductive barrier between tomato species. Plant J. 77: 727-736. doi:10.1111/tpj.12424. 
Table 1 Accessions, full-sib families and commercial cultivars used in crosses in season 1 (summer 2007/2008) and season 2 (summer 2009/2010), with taxonomic status, ploidy and geographic origin of accessions

\begin{tabular}{|c|c|c|c|c|c|c|c|c|c|}
\hline \multirow[t]{2}{*}{ Season } & \multicolumn{4}{|c|}{ Genetic Material } & \multirow[b]{2}{*}{$\begin{array}{c}\mathrm{N}^{\mathrm{o}} \\
\text { Plants }\end{array}$} & \multirow{2}{*}{$\begin{array}{l}\text { Location } \\
\text { in Argentina }\end{array}$} & \multirow{2}{*}{\multicolumn{2}{|c|}{$\begin{array}{l}\text { Geographic } \\
\text { coordinates }\end{array}$}} & \multirow{2}{*}{$\begin{array}{l}\text { Altitude } \\
\text { (m.a.s.l. }\end{array}$} \\
\hline & Type & Species $^{a}$ & $\underset{b}{\text { Ploidy }}$ & Denomination & & & & & \\
\hline \multirow[t]{18}{*}{1} & accession & grl & $2 x$ & ORHL4841 & 17 & La Poma, Salta & $24^{\circ} 33^{\prime} \mathrm{S}$ & $66^{\circ} 12^{\prime} \mathrm{O}$ & 3900 \\
\hline & & & & Oka7518 & 3 & San Carlos, Salta & $25^{\circ} 20^{\prime} \mathrm{S}$ & $65^{\circ} 53^{\prime} \mathrm{O}$ & 3500 \\
\hline & & & & OL4858 & 20 & Rosario de Lerma, Salta & $24^{\circ} 20^{\prime} \mathrm{S}$ & $66^{\circ} 05^{\prime} \mathrm{O}$ & 3500 \\
\hline & & & $4 \mathrm{x}$ & Oka7547 & 20 & Tambalaya, Jujuy & $23^{\circ} 36^{\prime} \mathrm{S}$ & $65^{\circ} 35^{\prime} \mathrm{O}$ & 3300 \\
\hline & & & & Oka7558 & 12 & San Salvador de Jujuy, Jujuy & $23^{\circ} 58^{\prime} \mathrm{S}$ & $65^{\circ} 38^{\prime} \mathrm{O}$ & 3200 \\
\hline & & & & Oka7565 & 19 & San Salvador de Jujuy, Jujuy & $23^{\circ} 58^{\prime} \mathrm{S}$ & $65^{\circ} 38^{\prime} \mathrm{O}$ & 3500 \\
\hline & & & & Oka7588 & 15 & Tilcara, Jujuy & $23^{\circ} 30^{\prime} \mathrm{S}$ & $65^{\circ} 27^{\prime} \mathrm{O}$ & 2700 \\
\hline & & & & Oka7594 & 17 & Humahuaca, Jujuy & $23^{\circ} 10^{\prime} \mathrm{S}$ & $65^{\circ} 11^{\prime} \mathrm{O}$ & 3500 \\
\hline & & spg & $2 \mathrm{x}$ & OL4911 & 27 & Chicoana, Salta & $25^{\circ} 10^{\prime} \mathrm{S}$ & $65^{\circ} 52^{\prime} \mathrm{O}$ & 3340 \\
\hline & & & & OL4916 & 11 & Chicoana, Salta & $25^{\circ} 10^{\prime} \mathrm{S}$ & $65^{\circ} 52^{\prime} \mathrm{O}$ & 3300 \\
\hline & & & & Oka5649 & 17 & Chicoana, Salta & $25^{\circ} 10^{\prime} \mathrm{S}$ & $65^{\circ} 52^{\prime} \mathrm{O}$ & 3000 \\
\hline & & & & Oka5662 & 27 & La Poma, Salta & $24^{\circ} 49^{\prime} \mathrm{S}$ & $66^{\circ} 10^{\prime} \mathrm{O}$ & 2620 \\
\hline & & & & Oka6147 & 27 & Belén, Catamarca & $27^{\circ} 29^{\prime} \mathrm{S}$ & $67^{\circ} 05^{\prime} \mathrm{O}$ & 1920 \\
\hline & cultivar & tbr & $4 x$ & Calén INTA & & --- & -- & & -- \\
\hline & & & & Kennebec & & --- & -- & & --- \\
\hline & & & & Pampeana INTA & & --- & -- & & --- \\
\hline & & & & Serrana INTA & & --- & -- & & --- \\
\hline & & & & Shepody & & --- & -- & & --- \\
\hline \multirow[t]{16}{*}{2} & accession & chc & $2 x$ & APEC1 & 13 & Balcarce, Buenos Aires & $37^{\circ} 45^{\prime} \mathrm{S}$ & $58^{\circ} 17^{\prime} \mathrm{O}$ & 128 \\
\hline & & & & HHR4039 & 10 & Castelar, Buenos Aires & $34^{\circ} 40^{\prime} \mathrm{S}$ & $58^{\circ} 40^{\prime} \mathrm{O}$ & 20 \\
\hline & full sib- & grl & $2 \mathrm{x}$ & ORHL4841.9 x Oka7518.5 & 11 & -- & -- & & -- \\
\hline & & & & OL4858.13 x ORHL4841.16 & 10 & -- & -- & & -- \\
\hline & & & & ORHL4841.14 x OL4858.17 & 6 & --- & -- & & --- \\
\hline & & & & OL4858.13 x Oka7518.3 & 23 & --- & -- & & -- \\
\hline & & spg & $2 \mathrm{x}$ & OL4911.19 x Oka5649.16 & 15 & --- & -- & & --- \\
\hline & & & & OL 4911.2 x OL4911.5 & 12 & --- & --- & & --- \\
\hline & & & & OL4911.19 x OL4916.7 & 16 & --- & -- & & --- \\
\hline & & & & OL4911.18 x Oka5649.12 & 10 & --- & -- & & --- \\
\hline & & spg $x$ grl & $2 x$ & OL4916.13 x ORHL4841.2 & 6 & --- & -- & & --- \\
\hline & & grl x spg & $2 \mathrm{x}$ & ORHL4841.3 x OL4916.12 & 5 & --- & -- & & --- \\
\hline & & & & ORHL4841.2 x OL4916.13 & 7 & --- & -- & & --- \\
\hline & cultivar & tbr & $4 x$ & Calén INTA & & --- & -- & & --- \\
\hline & & & & Pampeana INTA & & --- & -- & & --- \\
\hline & & & & Huinkul MAG & & --- & - & & --- \\
\hline
\end{tabular}

${ }_{b}^{a}$ grl: S. gourlayi; spg: S. spegazzinii; chc: S. chacoense; tbr: S. tuberosum ssp. tuberosum ${ }^{b} \mathrm{X}=12$ 
Table 2 Number of genotypic combinations according to type of cross and pollen-pistil relationships conducted with wild potato accessions, full-sib families and commercial cultivars over two seasons (pooled data). Note: Season 1 (summer 2006/07) included accessions of 2x and 4x S. gourlayi (grl), 2x S. spegazzinii (spg) and 4x S. tuberosum (tbr) cultivars; season 2 (summer 2009/10) included accessions of $2 \mathrm{x}$ S. chacoense, $2 \mathrm{x}$ intra- (grl x grl, $\operatorname{spg} \mathrm{x}$ spg) and inter-specific (spg $\mathrm{x}$ grl and grl $\mathrm{x}$ spg) full-sib families, and $4 \mathrm{x}$ tbr cultivars

\begin{tabular}{|c|c|c|c|c|c|c|}
\hline \multirow[t]{4}{*}{ Type of Cross $^{a}$} & \multirow{4}{*}{$\begin{array}{l}\mathrm{N}^{\mathrm{o}} \text { genotypic } \\
\text { combinations }\end{array}$} & \multicolumn{5}{|c|}{ Pollen-Pistil Relationship (\%) } \\
\hline & & \multirow[t]{3}{*}{ Compatible } & \multicolumn{4}{|c|}{ Incompatible } \\
\hline & & & \multirow[t]{2}{*}{ Stigma } & \multicolumn{3}{|c|}{ Style } \\
\hline & & & & $1 / 3$ & $2 / 3$ & $3 / 3$ \\
\hline \multicolumn{7}{|l|}{ Intraspecific } \\
\hline Within accession/family ${ }^{b}$ & 66 & 53.0 & 7.6 & 36.4 & 1.5 & 1.5 \\
\hline Between accession/family & 219 & 85.8 & 3.7 & 6.8 & 3.2 & 0.5 \\
\hline Interspecific $^{c}$ & 543 & 72.2 & 5.2 & 17.8 & 4.4 & 0.4 \\
\hline Total & 828 & 74.3 & 4.9 & 16.4 & 3.9 & 0.5 \\
\hline
\end{tabular}

${ }^{a}$ according to current taxonomy, based on morphological phenotypes

${ }^{b}$ family: includes full-sibs obtained from crosses between accessions classified as either the same or different taxonomic species

${ }^{c}$ genotypic combinations between inter-specific hybrid families and intra-specific hybrid families [e.g., (spg x grl) $\mathrm{x}$ (grl x grl)] are also included. 
Table 3 Number of genotypic combinations according to pollen-pistil relationships in intra- and inter-specific crosses, within and between ploidy levels, among wild potato accessions, full-sib families and commercial cultivars over two seasons (pooled data). Note: Season 1 (summer 2006/07) included accessions of 2x and 4x $S$. gourlayi (grl), 2x S. spegazzinii (spg) and 4x S. tuberosum (tbr) cultivars; season 2 (summer 2009/10) included accessions of $2 \mathrm{x}$ S. chacoense, $2 \mathrm{x}$ full-sib families (grl $\mathrm{x}$ grl, spg $\mathrm{x}$ spg, spg $\mathrm{x}$ grl and grl $\mathrm{x}$ spg) and $4 \mathrm{x}$ tbr cultivars

\begin{tabular}{|c|c|c|c|c|c|c|c|c|}
\hline \multicolumn{3}{|c|}{ Type of Cross ${ }^{a}$} & \multirow{4}{*}{$\begin{array}{l}\mathrm{N}^{\mathrm{o}} \text { genotypic } \\
\text { combinations }\end{array}$} & \multicolumn{5}{|c|}{ Pollen-Pistil Relationship (\%) } \\
\hline & & & & \multirow[t]{3}{*}{ Compatible } & \multicolumn{4}{|c|}{ Incompatible } \\
\hline & & & & & \multirow[t]{2}{*}{ Stigma } & \multicolumn{3}{|c|}{ Style } \\
\hline & & & & & & $1 / 3$ & $2 / 3$ & $3 / 3$ \\
\hline \multicolumn{9}{|c|}{ Intra-specific } \\
\hline $2 \mathrm{x}$ & $\mathrm{x}$ & $2 \mathrm{x}$ & 241 & 78.0 & 14.2 & 14.9 & 2.5 & 0.4 \\
\hline $2 \mathrm{x}$ & $\mathrm{x}$ & $4 x$ & 43 & 100.0 & 0.0 & 0.0 & 0.0 & 0.0 \\
\hline $4 \mathrm{x}$ & $\mathrm{x}$ & $2 \mathrm{x}$ & 41 & 80.5 & 7.3 & 7.3 & 4.9 & 0.0 \\
\hline $4 \mathrm{x}$ & $\mathrm{x}$ & $4 \mathrm{x}$ & 39 & 92.3 & 0.0 & 5.1 & 2.6 & 0.0 \\
\hline \multicolumn{9}{|c|}{ Inter-specific ${ }^{b}$} \\
\hline $2 \mathrm{x}$ & $\mathrm{x}$ & $2 \mathrm{x}$ & 169 & 79.3 & 4.7 & 9.5 & 5.3 & 1.2 \\
\hline $2 \mathrm{x}$ & $\mathrm{x}$ & $4 \mathrm{x}$ & 89 & 71.9 & 7.9 & 18.0 & 2.2 & 0.0 \\
\hline $4 x$ & $\mathrm{x}$ & $2 x$ & 70 & 52.9 & 7.1 & 35.7 & 2.9 & 1.4 \\
\hline $4 x$ & $\mathrm{x}$ & $4 x$ & 136 & 58.8 & 5.9 & 27.9 & 7.4 & 0.0 \\
\hline
\end{tabular}

${ }^{a}$ according to current taxonomy, based on morphological phenotypes

${ }^{b}$ genotypic combinations between inter-specific hybrid families and intra-specific hybrid families [e.g., (spg X grl) $\mathrm{x}(\mathrm{grl} \times \mathrm{grl})]$ are also included. 
Table 4 Number of observed pollen-pistil relationships -discriminated by site of pollen tube arrest- exhibited by single genotypes used as either the female or male parent in crosses with two or more genotypes over two seasons (pooled data). Note: Season 1 (summer 2006/07) included accessions of 2x and 4x S. gourlayi (grl), 2x $S$. spegazzinii (spg) and 4x S. tuberosum (tbr) cultivars; season 2 (summer 2009/10) included accessions of 2x S. chacoense, 2x full-sib families (grl $x$ grl, spg $\mathrm{x}$ spg, $\operatorname{spg} \mathrm{x}$ grl and grl $\mathrm{x}$ spg) and $4 \mathrm{x}$ tbr cultivars

\begin{tabular}{|c|c|c|c|c|c|c|c|}
\hline \multirow[t]{2}{*}{$\begin{array}{l}\mathrm{N}^{\mathrm{o}} \text { of observed pollen- } \\
\text { pistil relationships }\end{array}$} & \multicolumn{5}{|c|}{ Pollen-pistil relationship $^{a}$} & \multicolumn{2}{|c|}{$\begin{array}{l}\mathrm{N}^{\circ} \text { of single genotypes } \\
\text { crossed as }\end{array}$} \\
\hline & $\mathrm{C}$ & $\mathrm{I}_{\mathrm{S}}$ & $\mathrm{I}_{1 / 3}$ & $\mathrm{I}_{2 / 3}$ & $I_{3 / 3}$ & Female & Male \\
\hline \multirow[t]{4}{*}{1} & $\mathrm{x}$ & & & & & 84 & $\begin{array}{l}59 \\
\end{array}$ \\
\hline & & $\mathrm{x}$ & & & & 1 & - \\
\hline & & & $\mathrm{x}$ & & & 2 & 2 \\
\hline & & & & $\mathrm{x}$ & & 1 & - \\
\hline \multirow[t]{8}{*}{2} & $x$ & $x$ & & & & 7 & 2 \\
\hline & $\mathrm{x}$ & & $\mathrm{x}$ & & & 34 & 31 \\
\hline & $x$ & & & $\mathrm{x}$ & & 7 & 14 \\
\hline & $\mathrm{x}$ & & & & $\mathrm{x}$ & 1 & - \\
\hline & & $x$ & $\mathrm{x}$ & & & 2 & 2 \\
\hline & & $x$ & & $\mathrm{x}$ & & 1 & - \\
\hline & & & $\mathrm{x}$ & $\mathrm{x}$ & & 1 & - \\
\hline & & & $\mathrm{x}$ & & $\mathrm{X}$ & - & 1 \\
\hline \multirow[t]{4}{*}{3} & $\mathrm{x}$ & $x$ & $\mathrm{x}$ & & & 9 & 13 \\
\hline & $\mathrm{x}$ & & $\mathrm{x}$ & $\mathrm{x}$ & & 4 & 6 \\
\hline & $\mathrm{x}$ & & $\mathrm{x}$ & & $\mathrm{x}$ & 1 & - \\
\hline & $\mathrm{x}$ & $\mathrm{x}$ & & $\mathrm{x}$ & & 3 & 1 \\
\hline \multirow[t]{2}{*}{4} & $\mathrm{x}$ & $\mathrm{x}$ & $\mathrm{x}$ & $\mathrm{x}$ & & 3 & 5 \\
\hline & $\mathrm{x}$ & & $\mathrm{x}$ & $\mathrm{x}$ & $\mathrm{x}$ & - & 1 \\
\hline 5 & $\mathrm{x}$ & $\mathrm{x}$ & $\mathrm{x}$ & $\mathrm{x}$ & $\mathrm{x}$ & 1 & - \\
\hline
\end{tabular}

${ }^{a} \mathrm{C}$ : Compatible; incompatible in $\mathrm{I}_{\mathrm{S}}$ (stigma), and $\mathrm{I}_{1 / 3}$ (upper third), $\mathrm{I}_{2 / 3}$ (middle third) and $\mathrm{I}_{3 / 3}$ (bottom third) of style 
Table 5 Number of genotypic combinations -discriminated by type of pollen-pistil relationships- observed in a sample of intra- and interspecific crosses among potato accessions, families and cultivars. Pooled data

\begin{tabular}{|c|c|c|c|c|c|c|c|c|c|}
\hline \multirow[t]{2}{*}{ Season } & \multicolumn{4}{|c|}{ Cross } & \multicolumn{5}{|c|}{ Pollen-pistil relationship ${ }^{b}$} \\
\hline & species $^{a}$ & $\begin{array}{c}\text { accession/family/cultivar } \\
\circ \\
\end{array}$ & $\underset{\delta}{\operatorname{accession} / \text { family/cultivar }}$ & species $^{a}$ & $\mathrm{C}$ & $\mathrm{I}_{\mathrm{S}}$ & $\mathrm{I}_{1 / 3}$ & $\mathrm{I}_{2 / 3}$ & $\mathrm{I}_{3 / 3}$ \\
\hline \multirow[t]{30}{*}{1} & $2 \times$ grl & $\begin{aligned} & \text { Oka7518 } \\
* & \text { OL4858 }\end{aligned}$ & $\begin{array}{l}\text { OL4858 } \\
\text { Oka7518 }\end{array}$ & $2 \mathrm{x}$ grl & $\begin{array}{l}4 \\
4\end{array}$ & - & $\begin{array}{l}- \\
-\end{array}$ & - & - \\
\hline & " & $\begin{array}{c}\text { Oka7518 } \\
* \text { ORHL4841 }\end{array}$ & $\begin{array}{l}\text { ORHL4841 } \\
\text { Oka7518 }\end{array}$ & " & $\begin{array}{l}4 \\
7\end{array}$ & $\begin{array}{l}- \\
-\end{array}$ & $\begin{array}{l}- \\
-\end{array}$ & - & $\begin{array}{l}- \\
-\end{array}$ \\
\hline & $”$ & OL4858 & ORHL4841 & $"$ & 11 & - & - & 1 & - \\
\hline & $"$ & * ORHL4841 & OL4858 & $"$ & 11 & - & - & - & - \\
\hline & $"$ & OL4858 & Oka7588 & $4 \mathrm{x}$ grl & 5 & - & - & - & - \\
\hline & $"$ & OL4858 & OL4911 & $2 \mathrm{x} \mathrm{spg}$ & 6 & 2 & - & 1 & - \\
\hline & $2 \times \mathrm{spg}$ & * OL4911 & OL4858 & $2 \mathrm{x}$ grl & 5 & - & - & - & - \\
\hline & $2 \mathrm{x}$ grl & OL4858 & Kennebec & $4 \mathrm{x}$ tbr & 6 & 1 & 2 & 3 & - \\
\hline & $4 \mathrm{x}$ tbr & * Kennebec & OL4858 & $2 \mathrm{x}$ grl & 1 & - & 6 & 2 & - \\
\hline & $2 \times \mathrm{grl}$ & OLHR4841 & OL4911 & $2 \mathrm{x} \mathrm{spg}$ & 8 & - & 2 & 2 & - \\
\hline & $"$ & OLHR4841 & Oka5662 & $"$ & 4 & 1 & 2 & 1 & - \\
\hline & $2 x \operatorname{spg}$ & * Oka5662 & OLHR4841 & 2x grl & 4 & - & - & 1 & - \\
\hline & $4 \times$ grl & Oka7547 & Oka7558 & $4 \mathrm{x}$ grl & 1 & 1 & - & - & - \\
\hline & $"$ & Oka7565 & Oka4911 & $2 \mathrm{x} \mathrm{spg}$ & 7 & - & 1 & - & - \\
\hline & $"$ & Oka7595 & ORHL4841 & $2 \mathrm{x} \mathrm{grl}$ & 5 & - & - & 1 & - \\
\hline & $"$ & $"$ & Oka5649 & $2 \times \mathrm{spg}$ & 3 & 1 & - & 2 & - \\
\hline & $"$ & $"$ & Oka5662 & $"$ & 3 & 1 & - & 2 & - \\
\hline & $"$ & $"$ & Pampeana & $4 x$ tbr & 1 & - & 1 & 1 & - \\
\hline & $"$ & $"$ & OL4911 & $2 \mathrm{x} \mathrm{spg}$ & 14 & - & - & 2 & - \\
\hline & $2 \mathrm{x} \mathrm{spg}$ & Oka5649 & Oka4911 & $"$ & 13 & 2 & 3 & - & - \\
\hline & $"$ & $"$ & Calén & $4 \mathrm{x}$ tbr & 4 & 1 & 1 & - & - \\
\hline & $"$ & Oka5662 & Oka4911 & 2x spg & 21 & 1 & 2 & - & - \\
\hline & $"$ & $"$ & Oka5649 & $"$ & 5 & 1 & 1 & - & - \\
\hline & $"$ & $"$ & OL4858 & $2 \mathrm{x}$ grl & 6 & 2 & - & - & - \\
\hline & $"$ & Oka6147 & Oka4911 & $2 \mathrm{x} \mathrm{spg}$ & 8 & - & 1 & 1 & - \\
\hline & $"$ & Oka4911 & Oka5662 & $"$ & 10 & - & - & - & 1 \\
\hline & $"$ & $"$ & Pampeana & $4 \mathrm{x}$ tbr & 5 & - & 2 & - & - \\
\hline & $"$ & OL4916 & OL4911 & $2 \mathrm{x} \mathrm{spg}$ & 9 & - & - & - & - \\
\hline & $"$ & $"$ & Oka5649 & $"$ & 13 & - & - & - & - \\
\hline & $4 \mathrm{x}$ tbr & Calén & Oka7547 & $4 \mathrm{x}$ grl & 4 & - & 1 & - & - \\
\hline \multirow[t]{9}{*}{2} & $2 x \mathrm{chc}$ & APEC1 & APEC1 & $2 \mathrm{x}$ chc & 10 & 5 & 10 & - & - \\
\hline & $"$ & $"$ & (OL4916.13 x ORHL4841.2) & spg xgrl & 1 & 1 & 1 & 1 & - \\
\hline & spg x grl & (OL4916.13 x ORHL4841.2) & APEC1 & $2 \mathrm{x}$ chc & 5 & - & 1 & 1 & - \\
\hline & $2 \mathrm{x}$ chc & APEC1 & Huinkul & $4 \mathrm{x}$ tbr & - & 2 & 1 & 1 & - \\
\hline & $4 \mathrm{x}$ tbr & * Huinkul & APEC1 & $2 \mathrm{x}$ chc & 1 & 1 & 6 & - & - \\
\hline & spg $\times$ spg & (OL 4911.2 x OL4911.5) & $"$ & $"$ & 3 & - & - & - & 1 \\
\hline & 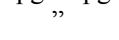 & (OL4911.19 x OL4916.7) & (OL4916.13 x ORHL4841.2) & spg x grl & 5 & - & - & - & - \\
\hline & $"$ & & (OL4911.19 x OL4916.7) & spg X spg & 5 & - & 4 & 1 & - \\
\hline & spg x grl & (OL4916.13 x ORHL4841.2) & $\begin{array}{l}\text { (ORHL4841.14 x } \\
\text { OL4858.17) }\end{array}$ & grl x grl & 6 & - & 1 & - & - \\
\hline
\end{tabular}

${ }^{a}$ chc: $S$. chacoense; grl: S. gourlayi; spg: S. spegazzinii; tbr: S. tuberosum ssp. tuberosum

${ }^{b} \mathrm{C}$ : Compatible; incompatible in $\mathrm{I}_{\mathrm{S}}$ (stigma), and $\mathrm{I}_{1 / 3}$ (upper third), $\mathrm{I}_{2 / 3}$ (middle third) and $\mathrm{I}_{3 / 3}$ (bottom third) of style

*reciprocal crosses 
Table 6 Pollen-pistil relationships exhibited by individual genotypes of one inter-specific wild potato family (spg OL4916.13 x grl ORHL4841.2) -whose progenitors had exhibited only compatible relationships in, respectively, 15 and 20 intra- and inter-specific genotypic combinations- upon crossing within the family and with genotypes from intra-specific S. gourlayi (grl) and S. spegazzinii (spg) families, and one S. chacoense (chc) accession. Pooled data

\begin{tabular}{|c|c|c|c|c|c|c|c|c|c|}
\hline \multicolumn{4}{|c|}{ Cross } & \multicolumn{6}{|c|}{ Pollen-pistil relationships ${ }^{b}$} \\
\hline species $^{\mathrm{a}}$ & accession/family $q$ & accession/family $\precsim$ & species & $\begin{array}{l}\text { No. genotypic } \\
\text { combinations }\end{array}$ & $\mathrm{C}$ & $\mathrm{I}_{\mathrm{S}}$ & $\mathrm{I}_{1 / 3}$ & $\mathrm{I}_{2 / 3}$ & $\mathrm{I}_{3 / 3}$ \\
\hline $\operatorname{spg} \times 2 \times$ grl & $\begin{array}{l}\text { (OL4916.13 x } \\
\text { ORHL4841.2) }\end{array}$ & $\begin{array}{l}\text { (OL4916.13 x } \\
\text { ORHL4841.2) }\end{array}$ & $\operatorname{spg} \times 2 \times$ grl & 11 & 8 & - & 3 & - & - \\
\hline $\operatorname{spg} \times 2 \times$ grl & $\begin{array}{l}\text { (OL4916.13 x } \\
\text { ORHL4841.2) }\end{array}$ & Various & $\begin{array}{l}\text { spg or } \\
2 \mathrm{x} \text { grl }\end{array}$ & 12 & 10 & - & 2 & - & - \\
\hline $\begin{array}{l}\text { spg or } \\
2 \mathrm{x} \text { grl }\end{array}$ & Various & $\begin{array}{l}\text { (OL4916.13 x } \\
\text { ORHL4841.2) }\end{array}$ & $\operatorname{spg} \times 2 \times$ grl & 7 & 6 & - & 1 & - & - \\
\hline$"$ & ” & APEC1 & $2 x \mathrm{chc}$ & 9 & 8 & - & - & 1 & - \\
\hline $2 \mathrm{x}$ chc & APEC1 & $\begin{array}{l}\text { (OL4916.13 x } \\
\text { ORHL4841.2) }\end{array}$ & $\operatorname{spg} \times 2 \times$ grl & 5 & 1 & 2 & 1 & 1 & - \\
\hline
\end{tabular}

${ }^{a}$ chc: $S$. chacoense; grl: S. gourlayi; spg: S. spegazzinii

${ }^{b} \mathrm{C}$ : Compatible; incompatible in $\mathrm{I}_{\mathrm{S}}$ (stigma), and $\mathrm{I}_{1 / 3}$ (upper third), $\mathrm{I}_{2 / 3}$ (middle third) and $\mathrm{I}_{3 / 3}$ (bottom third) of style 
Table 7 Pollen-pistil relationships observed in a sample of genotypic combinations among wild potatoes and cultivars and their reciprocals, excluding combinations that were compatible in both directions, carried out in two seasons

\begin{tabular}{|c|c|c|c|c|}
\hline \multirow[t]{2}{*}{ Season } & \multicolumn{2}{|c|}{ Genotypic combination $^{a}$} & \multicolumn{2}{|c|}{ Pollen-Pistil Relationship ${ }^{b}$} \\
\hline & Female (F) & Male (M) & $\mathrm{F} \times \mathrm{M}$ & $\mathrm{M} \times \mathrm{F}$ \\
\hline \multirow[t]{23}{*}{1} & $2 \mathrm{x} \operatorname{grl} \mathrm{x} 4 \mathrm{x}$ tbr & & & \\
\hline & OL4858.3 & Kennebec & $\mathrm{C}$ & $\mathrm{I}_{2 / 3}$ \\
\hline & ORHL4841.8 & $"$ & $\mathrm{C}$ & $\mathrm{I}_{2 / 3}$ \\
\hline & ORHL4841.11 & $"$ & $\mathrm{C}$ & $\mathrm{I}_{1 / 3}$ \\
\hline & ORHL4841.15 & $"$ & $\mathrm{C}$ & $\mathrm{I}_{1 / 3}$ \\
\hline & ORHL4841.17 & $"$ & $\mathrm{C}$ & $\mathrm{I}_{1 / 3}$ \\
\hline & ORHL4841.18 & $"$ & $\mathrm{C}$ & $\mathrm{I}_{2 / 3}$ \\
\hline & OL4858.8 & $"$ & $\mathrm{I}_{\mathrm{S}}$ & $\mathrm{I}_{1 / 3}$ \\
\hline & OL4858.10 & $"$ & $\mathrm{I}_{1 / 3}$ & $\mathrm{I}_{2 / 3}$ \\
\hline & OL4858.16 & $"$ & $\mathrm{I}_{2 / 3}$ & $\mathrm{I}_{1 / 3}$ \\
\hline & $\begin{array}{r}2 \mathrm{x} \text { grl } \mathrm{x} 2 \mathrm{x} \text { grl } \\
\text { OL4858.16 }\end{array}$ & ORHL4841.9 & $\mathrm{I}_{2 / 3}$ & $\mathrm{C}$ \\
\hline & $\begin{array}{l}\text { 2x grl x 2x spg } \\
\text { ORHL4841.2 }\end{array}$ & Oka5662.14 & $\mathrm{I}_{1 / 3}$ & $\mathrm{C}$ \\
\hline & $2 \times \operatorname{spg} \times 2 \times \operatorname{spg}$ & & & \\
\hline & OL4911.6 & OL4911.9 & $\mathrm{I}_{\mathrm{S}}$ & $\mathrm{C}$ \\
\hline & Oka5649.6 & Oka5662.25 & $\mathrm{C}$ & $\mathrm{I}_{\mathrm{S}}$ \\
\hline & $4 \mathrm{x}$ grl $\times 4 \mathrm{x}$ tbr & & & \\
\hline & Oka7547.10 & Calén & $\mathrm{C}$ & $\mathrm{I}_{1 / 3}$ \\
\hline & Oka7547.13 & $"$ & $\mathrm{C}$ & $\mathrm{I}_{1 / 3}$ \\
\hline & Oka7565.20 & ” & $\mathrm{I}_{1 / 3}$ & $\mathrm{C}$ \\
\hline & Oka7565.11 & Kennebec & $\mathrm{C}$ & $\mathrm{I}_{1 / 3}$ \\
\hline & $2 \mathrm{x} \operatorname{spg} \mathrm{x} 4 \mathrm{x}$ tbr & & & \\
\hline & OL4911.5 & Kennebec & $\mathrm{C}$ & $\mathrm{I}_{1 / 3}$ \\
\hline & Oka5649.2 & Calén & $\mathrm{I}_{1 / 3}$ & $\mathrm{I}_{1 / 3}$ \\
\hline \multirow[t]{17}{*}{2} & $2 x \operatorname{chc} x 2 x(\operatorname{spg} x$ grl $)$ & & & \\
\hline & APEC1.5 & (OL4916.13 x ORHL4841.2).3 & $\mathrm{I}_{2 / 3}$ & $\mathrm{I}_{2 / 3}$ \\
\hline & APEC1.11 & $"$ & $\mathrm{I}_{1 / 3}$ & $\mathrm{C}$ \\
\hline & APEC1.3 & (OL4916.13 x ORHL4841.2).1 & $\mathrm{I}_{\mathrm{S}}$ & $\mathrm{C}$ \\
\hline & $2 \times \operatorname{chc} \times 2 \times(\operatorname{spg} \times \operatorname{spg})$ & & & \\
\hline & APEC1.2 & (OL 4911.02 x OL4911.5).3 & $\mathrm{I}_{1 / 3}$ & $\mathrm{C}$ \\
\hline & $2 x \operatorname{chc} \times 2 \times$ chc & & & \\
\hline & APEC1.5 & APEC1.4 & $\mathrm{I}_{\mathrm{S}}$ & $\mathrm{C}$ \\
\hline & APEC1.5 & APEC1.3 & $\mathrm{I}_{1 / 3}$ & $\mathrm{I}_{1 / 3}$ \\
\hline & $2 \mathrm{x}$ che $\mathrm{x} 2 \mathrm{x}(\mathrm{grl} \times \mathrm{grl})$ & & & \\
\hline & APEC1.3 & $(\mathrm{OL} 4858.13 \times$ Oka7518.03).24 & $\mathrm{I}_{2 / 3}$ & $\mathrm{I}_{2 / 3}$ \\
\hline & $2 \mathrm{x}$ chc $\mathrm{x} 4 \mathrm{x}$ tbr & & & \\
\hline & APEC1.1 & Huinkul & $\mathrm{I}_{1 / 3}$ & $\mathrm{I}_{1 / 3}$ \\
\hline & APEC1.2 & $"$ & $\mathrm{I}_{2 / 3}$ & $\mathrm{I}_{1 / 3}$ \\
\hline & APEC1.5 & $”$ & $\mathrm{I}_{1 / 3}$ & $\mathrm{I}_{1 / 3}$ \\
\hline & $2 \mathrm{x} \operatorname{spg} \times 2 \mathrm{x} \operatorname{spg}$ & & & \\
\hline & $($ OL4911.19 x OL4916.07).10 & (OL4911.19 x OL4916.07).16 & $\mathrm{I}_{\mathrm{S}}$ & $\mathrm{I}_{1 / 3}$ \\
\hline
\end{tabular}

${ }^{a}$ chc: S. chacoense; grl: S. gourlayi; spg: S. spegazzinii; tbr: S. tuberosum ssp. tuberosum ${ }^{b} \mathrm{C}$ : Compatible; incompatible in $\mathrm{I}_{\mathrm{S}}$ (stigma), and $\mathrm{I}_{1 / 3}$ (upper third), $\mathrm{I}_{2 / 3}$ (middle third) and $\mathrm{I}_{3 / 3}$ (bottom third) of style 


\section{LIST OF FIGURES}

Fig. 1 Examples of pollen-pistil relationships in wild and cultivated potatoes: compatibility (a) and incompatibility at stigma (b), top (c), middle (d) and bottom third (e) of the style. Pollen tubes in black; black arrows: site of detention of pollen tube growth. Bars, $0.1 \mathrm{~cm}$

Fig. 2 Example of compatibility relationships in wild potatoes observed in season 2. Each plant represents one genotype; each colour represents one accession/family. Arrow direction= direction of pollination. Pollen-pistil relationships: compatibility (normal arrow), incompatibility (truncated arrow head; in black: stigma; white: $1 / 3$ of style; grey: $2 / 3$ of style; discontinued black: $3 / 3$ of style). chc: $S$. chacoense; grl: $S$. gourlayi; spg: $S$. spegazzinii. 


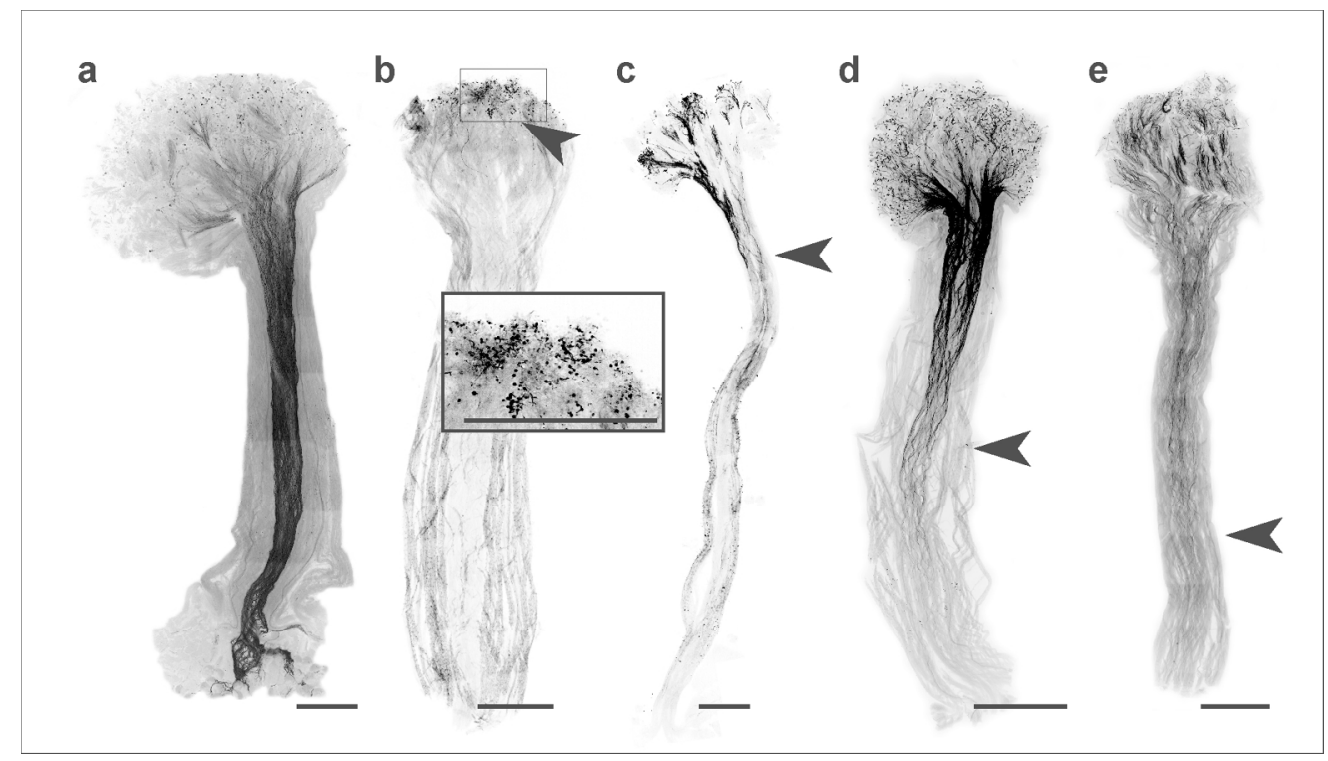

Fig. 1 Examples of pollen-pistil relationships in wild and cultivated potatoes: compatibility (a) and incompatibility at stigma (b), top (c), middle (d) and bottom third (e) of the style. Pollen tubes in black; black arrows: site of detention of pollen tube growth. Bars, $0.1 \mathrm{~cm}$

$170 \times 97 \mathrm{~mm}(300 \times 300 \mathrm{DPI})$ 


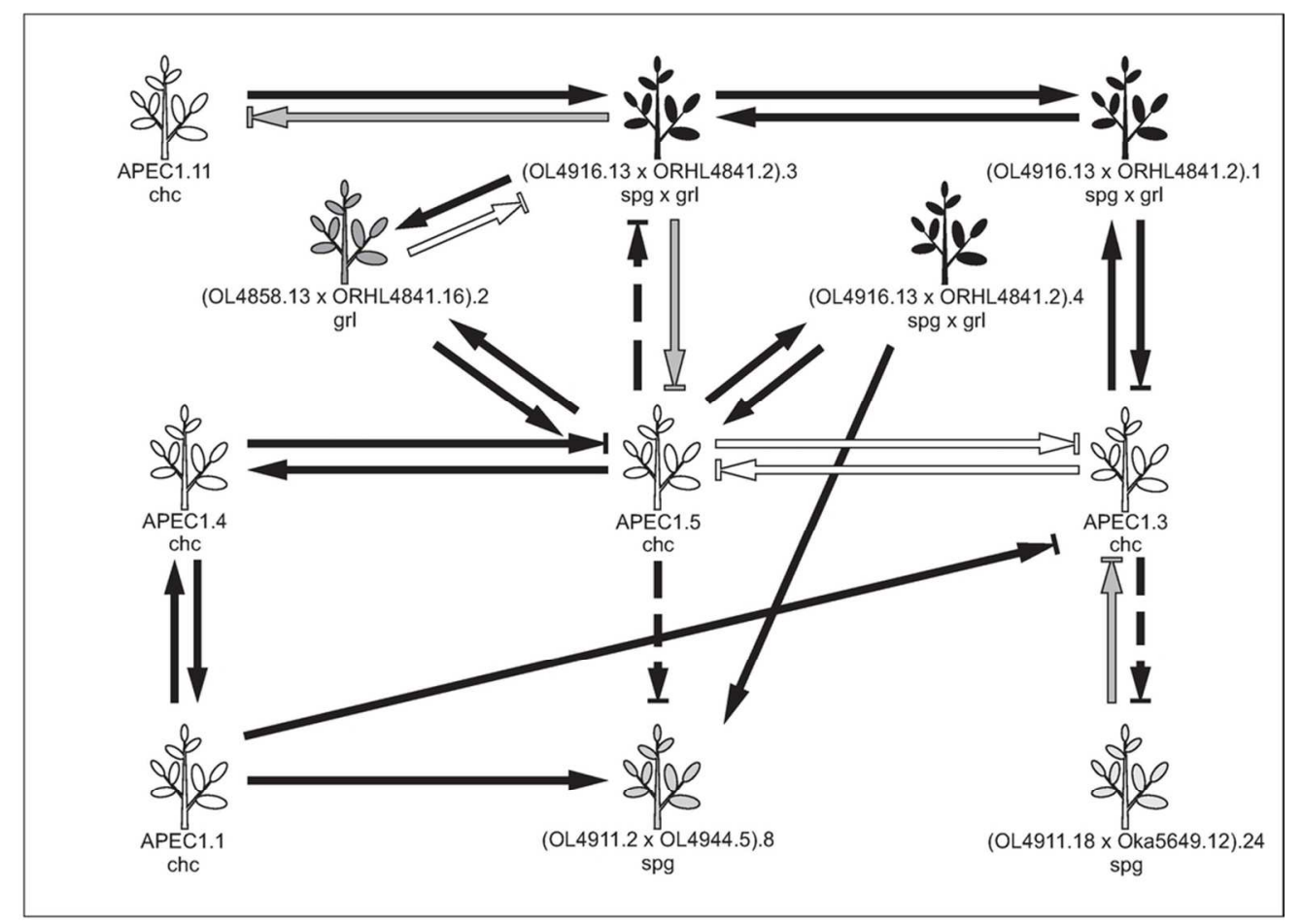

Fig. 2 Example of compatibility relationships in wild potatoes observed in season 2. Each plant represents one genotype; each colour represents one accession/family. Arrow direction= direction of pollination. Pollenpistil relationships: compatibility (normal arrow), incompatibility (truncated arrow head; in black: stigma; white: $1 / 3$ of style; grey: $2 / 3$ of style; discontinued black: $3 / 3$ of style). chc: S. chacoense; grl: S. gourlayi; spg: S. spegazzinii.

$92 \times 66 \mathrm{~mm}(300 \times 300 \mathrm{DPI})$ 